Cornell University Law School Scholarship@Cornell Law: A Digital Repository

$9-2016$

\title{
Revisiting Eisenberg and Plaintiff Success: State Court Civil Trial and Appellate Outcomes
}

Michael Heise

Cornell Law School, michael.heise@cornell.edu

Martin T. Wells

Cornell University,mtw1@cornell.edu

Follow this and additional works at: http://scholarship.law.cornell.edu/facpub

Part of the Civil Procedure Commons, and the Litigation Commons

\section{Recommended Citation}

Michael Heise and Martin T. Wells, "Revisiting Eisenberg and Plaintiff Success: State Court Civil Trial and Appellate Outcomes," 13 Journal of Empirical Legal Studies (2016)

This Article is brought to you for free and open access by the Faculty Scholarship at Scholarship@Cornell Law: A Digital Repository. It has been accepted for inclusion in Cornell Law Faculty Publications by an authorized administrator of Scholarship@Cornell Law: A Digital Repository. For more information, please contact jmp8@cornell.edu. 


\title{
JOURNAL OF \\ EMPIRICAL LEGAL STUDIES
}

Journal of Empirical Legal Studies

Volume 13, Issue 3, 516-535, September 2016

\section{Revisiting Eisenberg and Plaintiff Success: State Court Civil Trial and Appellate Outcomes}

\author{
Michael Heise and Martin T. Wells*
}

\begin{abstract}
Despite what Priest-Klein theory predicts, in earlier research on federal civil cases, Eisenberg found an association between plaintiff success in pretrial motions and at trial. Our extension of Eisenberg's analysis 20 years later into the state court context, however, does not uncover any statistically significant association between a plaintiff's success at trial and preserving that trial victory on appeal. Our results imply that a plaintiff's decision to pursue litigation to a trial court conclusion is analytically distinct from the plaintiff's decision to defend an appeal of its trial court win brought by a disgruntled defendant. We consider various factors that likely account for the observed differences that distinguish our results from Eisenberg's. First, legal cases that persist to an appellate outcome are a filtered subset of underlying trials and legal disputes and various selection effects inform much of this case filtering. Second, where Eisenberg analyzed the relation between pretrial motions and trial outcomes in federal courts, we assess possible relations between trial and appellate court outcomes in state courts. The pretrial and trial context and the trial and appeals context likely differ in ways that disturb plaintiff success. Third, while Eisenberg studied federal cases between 1978-1985 we study state cases between 2001-2009. In addition to differences between federal and state civil cases, the composition of cases that selected into formal litigation may have evolved over time.
\end{abstract}

\section{INTRODUCTION}

Selection effect theory implies that one cannot draw reliable inferences about the larger legal system from studies of tried cases. ${ }^{1}$ This general point has been extended to include similar inferences moored in published legal opinions. ${ }^{2}$ Problems with such

\footnotetext{
*Address correspondence to Michael Heise, email: michael.heise@cornell.edu. Heise is Professor, Cornell Law School; Wells is Professor, Department of Statistical Science, Cornell University. We thank participants in the 2015 Theodore Eisenberg Memorial Empirical Legal Studies Conference at Tel Aviv University, participants in the 2016 Midwest Political Science Association Annual Meeting, Ronen Avraham, Dawn M. Chutkow, Kevin Clermont, Jeff Rachlinski, Zach Clopton, and three anonymous referees for their comments on earlier drafts.
}

${ }^{1}$ See, e.g., George L. Priest \& Benjamin Klein, The Selection of Disputes for Litigation, 13 J. Legal Stud. 1 (1984).

${ }^{2}$ See, e.g., Theodore Eisenberg \& Stewart J. Schwab, What Shapes Perceptions of the Federal Court System? 56 U. Chi. L. Rev. 501 (1989). 
attempted inferences flow from distortions uniquely attributable to systematic, nonrandom differences that distinguish the pool of tried cases (and tried cases that generate published judicial opinions) from the larger universe of legal disputes. Case selection occurs because disputes whose legal outcome is comparatively clear for either the plaintiff or defendant are more likely to settle relatively quickly, leaving the comparatively more difficult (legal or fact) cases to proceed to trial (and, perhaps, a published legal opinion). One well-tested research hypothesis flowing from selection theory involves the ex ante prediction that the subpool of cases that proceed to trial should generate a plaintiff trial success rate of approximately 50 percent. ${ }^{3}$ Although this particular prediction from the Priest-Klein theory has been severely challenged, ${ }^{4}$ other hypotheses prompted by selection effect theory remain underexplored. Although selection theory and the related 50 percent hypothesis are linked inextricably in the scholarly literature, it is important to note that evidence rejecting the 50 percent hypothesis does not necessarily require a rejection of selection theory. ${ }^{5}$

Despite extensive scholarly attention to the subpool of legal disputes that ripen into litigation resolved by formal trial, far more cases are resolved at the pretrial motion stage than by a trial on the merits. Extending the Priest-Klein selection theory to the pretrial motion context generates a prediction that, as a result of selection effects, in remaining cases no systematic relation connects a plaintiff's success in pretrial motions and subsequent success at trial. Indeed, if anything, the additional information contained in pretrial motion rulings and supplied to litigants should help filter the subpool of cases that proceed to trial in a manner that nudges plaintiff success rate at trial closer to the predicted 50 percent. In contrast to what Priest-Klein theory implies, however, in one of the few empirical studies of this issue, and in one of his initial empirical projects, Professor Eisenberg explored all civil (nonbankruptcy) cases concluded in federal districts courts from 1978-1985 and found a "significant positive relationship between success rates at trial and success rates on pretrial motion across civil litigation categories."

More than two decades later, and seeking to respond to, build up, and expand Eisenberg's prior work, this article reports results from a study focusing on a relatedthough distinct-slice of the civil litigation world. Specifically, this article sets out to extend Eisenberg's focus by exploring the potential relation between plaintiff success at trial and on appeal in state civil courts from 2001-2009. While Eisenberg found empirical support linking plaintiffs' pretrial success and success at trial, we, by contrast, did

\footnotetext{
${ }^{3}$ See, e.g., Priest \& Klein, supra note 1; George L. Priest, Reexamining the Selection Hypothesis: Learning from Wittman's Mistakes, 14 J. Legal Stud. 215 (1985); Donald Wittman, Is the Selection of Cases for Trial Biased? 14 J. Legal Stud. 185 (1985).

${ }^{4}$ See, e.g., Theodore Eisenberg, Testing the Selection Effect: A New Theoretical Framework with Empirical Tests, 19 J. Legal Stud. 337 (1990).
}

${ }^{5}$ For a fuller discussion of this point, see, e.g., id.

${ }^{6}$ Theodore Eisenberg, The Relationship Between Plaintiff Success Rates Before Trial and at Trial, 154 J. Royal Statistical Soc'y, Series A 111, 112 (1991). 
not find similar evidence linking plaintiffs' success at trial with subsequent success on appeal. We consider various explanations for these seemingly inconsistent findings in the discussion.

\section{LiterAtURE REVIEW}

Selection effect concerns occupy much of the scholarly literature that delves into whether and, if so, to what degree data on tried cases can support more general inferences to the much broader universe of legal disputes from which tried cases emerge. According to the Priest-Klein model, cases resist settlement and proceed to a judicial resolution if the litigating parties are overly optimistic about their chances for success. The general model (naively) assumes that the litigating parties have similar stakes involved, risk appetites, and information. If litigants' errors about their prospects for trial (or appellate) success are distributed symmetrically, then a plaintiff's win rate at trial (or an appellant's win rate on appeal) should approach 50 percent as trials and appeals partly reflect errors in parties' expectations about likelihood of success. ${ }^{7}$ Subsequent empirical tests of the Priest-Klein model's central 50 percent prediction, including some of our own, reveal complicating wrinkles and challenges to the model's assumption about parties' equal stakes. ${ }^{8}$

As formal litigation progresses it is plausible to assume that both litigating parties gain additional information about the strength of their respective legal positions. For example, results from pretrial motions should provide litigants important information supplied by a third party about their contested legal issues. This additional information should also inform and refine both parties' subsequent settlement activity. The PriestKlein theory implies that the subset of cases that proceeds to trial after pretrial motion rulings includes those cases where both parties retain optimism about their legal prospects despite the additional information provided by the results from pretrial hearings. Indeed, if anything (and holding all the assumptions underneath the Priest-Klein theory constant), the additional information supplied by rulings on pretrial motions should, on balance, further filter the cases that proceed to trial in a manner that nudges the plaintiff closer toward the predicted 50 percent win rate. To the extent that cases that proceed to a trial for resolution likely systematically differ from cases that settle after pretrial motions are resolved, as Priest-Klein theory predicts, we should expect, ex ante, no systematic relation between a plaintiff's pretrial motion success and later success at trial.

\footnotetext{
${ }^{7}$ Priest \& Klein, supra note 1, at 4-5.

${ }^{8}$ See, e.g., Theodore Eisenberg \& Michael Heise, Plaintiphobia in State Courts Redux? An Empirical Study of State Court Trials on Appeal, 12 J. Empirical Legal Stud. 100 (2015); Theodore Eisenberg \& Henry S. Farber, Why Do Plaintiffs Lose Appeals? Biased Trial Courts, Litigious Losers, or Low Trial Win Rates? 15 Am. L. \& Econ. Rev. 73 (2013); Theodore Eisenberg \& Michael Heise, Plaintiphobia in State Courts? An Empirical Study of State Court Trials on Appeal, 38 J. Legal Stud. 121 (2009); Kevin Clermont \& Theodore Eisenberg, Appeal from Jury or Judge Trial: Defendants' Advantage, 3 Am. L. \& Econ. Rev. 125 (2001); Joel Waldfogel, The Selection Hypothesis and the Relationship Between Trial and Plaintiff Victory, 103 J. Pol. Econ. 229 (1995); Eisenberg, Testing, supra note 4.
} 
Eisenberg's 1991 study brings data to this question by focusing on the relation between tried cases and cases informed by pretrial motions. ${ }^{9}$ Using a data set that includes all reported pretrial motion and trial outcomes in all nonbankruptcy civil cases tried in all U.S. federal courts between 1978 and $1985(N=204,560$ motions; $N=57,206$ tried cases) for which the Administrative Office of the U.S. Courts reports a judgment for the prevailing party, Eisenberg finds, in contrast to what Priest-Klein theory implies, a "large, significant positive relationship between [plaintiff] success rates at trial and [plaintiff] success rates on pretrial motions across all civil litigation categories." 10

Using the same Administrative Office data set (1978-1985), in a separate article Eisenberg explored the relation between plaintiff success rates in settled cases and litigated cases, with particular attention to the possible influence of case categories. Eisenberg coded "litigated" cases to include resolved by pretrial motion and tried cases. ${ }^{11}$ Organizing the plaintiff success rates by case categories, Eisenberg again found a strong statistical relation between plaintiffs' success in settled and litigated cases across case categories. ${ }^{12}$ Eisenberg noted that his findings suggest that case-category-specific factors inform outcome patterns more than procedural stages. That is, within case categories, plaintiffs' success rates in cases that settle prior to any pretrial motions resemble plaintiffs' success rates in cases that persist to either pretrial motions or trials. Eisenberg suggested that features particular to each case category, including litigation cost, asymmetrical knowledge, incentives, and legal doctrine, help account for the similarities that "transcend settlement, pretrial, and trial disposition stages." 13

One important limitation of the existing empirical literature flows from the dominance of data from federal courts and the structural ways in which federal and state courts differ. In particular, in the federal court context, efforts to study patterns of plaintiff success throughout the litigation cycle, including plaintiffs' pretrial and trial success, magistrate judges raise the specter of a potential lack of independence. Magistrate judges perform an array of tasks in federal courts that varies across time and federal districts and, sometimes, within federal districts. ${ }^{14}$ The implications of this variation from a research design standpoint are important. One extreme would involve a magistrate judge who rules on a pretrial motion and then later fully participates in the trial.

\footnotetext{
${ }^{9}$ See Eisenberg, Relationship, supra note 6.

${ }^{10}$ Id. at 112 .

${ }^{11}$ Theodore Eisenberg, Negotiation, Lawyering, and Adjudication: Kritzer on Brokers and Deals, 19 Law \& Soc. Inquiry 275, 292 (1994).

${ }^{12}$ Id. at 293.

${ }^{13} \mathrm{Id}$.

${ }^{14}$ For a comprehensive discussion of magistrate judges' role in federal courts and how it has evolved over time, see, e.g., Tim A. Baker, The Expanding Role of Magistrate Judges in the Federal Courts, 39 Val. U. L. Rev. 661 (2005); R. Lawrence Dessem, The Role of the Federal Magistrate Judge in Civil Justice Reform, 67 St. John's L. Rev. 799 (1993).
} 
In this setting one would expect, ex ante, to find a robust (and elevated) relation between plaintiff success on a motion and plaintiff success at trial as the same individual (a magistrate judge) would decide at both occasions. This would contrast, however, to situations where a magistrate judge rules on a pretrial motion and a district judge rules at the full merits trial. In the latter setting, greater independence can be assumed as different individuals are ruling at two different points in a lawsuit.

Regrettably, neither of Eisenberg's studies codes for these possibilities (even assuming the information for such coding was available). Moreover, it is not entirely clear whether consistent norms existed regarding the allocation of tasks between district and magistrate judges and, if consistent norms did exist, what they may have been during the timeframe of data used in Eisenberg's studies (1978-1985). What is quite clear today is that the allocation of federal and magistrate judges' roles varies tremendously both across and within federal districts.

Uncertainty about how federal district and magistrate judges allocated their tasks in 1978-1985 greatly complicates efforts to assess the degree of independence that exists in Eisenberg's data sets. What is clear, however (and described more fully below), is that independence can be comfortably assumed in the data set used in our study of possible relations between plaintiffs' success at trial and on appeal in state courts. U.S. state courts do not use state versions of magistrate judges. As a consequence, we can be quite confident that different people presided over the state trial and appellate court outcomes in our data set. Or, to put the point more plainly, an appellant unsatisfied by a trial court outcome in a state court can appeal her case to a state appellate court and the appeal will be decided by someone other than the trial court judge.

\section{Data, Methodology, and Research Design}

Two distinct, though related, data sets supply the data necessary for this study and form the single largest and most comprehensive state civil appeals data set of which we are aware.

Our state data set combines two separate (2001 and 2005), two-part (trial and appellate) data sets. All components of our state data set draw from the "Civil Justice Survey of State Courts," a project of the National Center for State Courts (NCSC) and the U.S. Bureau of Justice Statistics (BJS), which gathers data directly from state court clerks' offices on tort, contract, and property cases disposed of by trial during calendar years 2001 and 2005.

The 2001 trial data set includes state courts of general jurisdiction in a random sample of 46 of the nation's 75 most populous counties. The 75 counties from which the sample of 46 was drawn include approximately 37 percent of the 1990 U.S. population and account for approximately one-half of all civil lawsuits filed in state courts. The 2001 trial data set includes information on 8,038 trials. $^{15}$

\footnotetext{
${ }^{15}$ For a general description of the appeals data set, see Thomas H. Cohen \& Steven K. Smith, U.S. Dep't of Justice, Civil Justice Survey of State Courts, 2001: Civil Trial Cases and Verdicts in Large Counties, 2001, at 4-5 (U.S. Gov't Printing Office, Apr. 2004); Codebook, Inter-University Consortium for Political and Social Research, Civil Justice Survey of State Courts, 2001 [United States], Study No. 3957.
} 
The second (appellate) part of the 2001 state data set complemented the trial data study by tracking the 1,204 cases where the trial verdict or judgment, concluded by trial during calendar year 2001, was appealed to an intermediate appellate court or a state's court of last resort by April $2005^{16}$ (U.S. Department of Justice 2005). Of this universe of 1,204 appeals, 47 (3.9 percent) were excluded from many of our analyses because the appeals lacked critical information about which party prevailed at trial. Merging the trial and appellate data sets generated our 2001 data set: a longitudinal view of the universe of state appellate activity drawn from the most representative sample of state trial activity in the United States in 2001.

The development of our 2005 state data set closely (but not exactly) tracks the development of the 2001 state data set. The 2005 Civil Justice Survey data set included 46 of the 75 most populous counties selected to maintain backwards compatibility with earlier Civil Justice Surveys data sets (including the 2001 data set). The 2005 survey expanded coverage, however, by adding 110 additional counties to represent the 3,066 smaller counties not found among the country's 75 largest counties. ${ }^{17}$ The 2005 data set includes 8,872 concluded trials from 141 different counties and 40 different states.

Similar to the 2001 trial data set, the 2005 trial data set was complemented by an appellate data set that tracked the 1,290 cases where the trial verdict or judgment, concluded by trial during calendar year 2005, engaged in an appeal to an intermediate appellate court or a state's court of last resort by December 2009. ${ }^{18}$ Of this universe of 1,290 initial appeals, 20 appeals (1.6 percent) were excluded from many of our analyses because the appeals lacked critical information about which party prevailed at trial.

The final step in the creation of our state data set involved merging the 2001 and 2005 data sets. Before we did so, however, we filtered out cases where it was not clear that the nature of the appeal was adverse. For example, if the trial court ruled for the plaintiff, most would expect that the defendant would be the appellant in any appeal. Conversely, where the trial court ruled for the defendant, one would expect the plaintiff to be the appellant. For the most part (in 81.4 percent of the appeals), these

\footnotetext{
${ }^{16}$ For a general description of the appeals data set, see Thomas H. Cohen, U.S. Dep't of Justice, Appeals from General Civil Trials in 46 Large Counties, 2001-2005 (U.S. Gov't Printing Office, June 2006); Codebook, InterUniversity Consortium for Political and Social Research, Supplemental Survey of Civil Appeals, 2001 [United States], Study No. 4539 .

${ }^{17}$ For a summary of the data and methodology, see Bureau of Justice Statistics Special Report: Civil Justice Survey of State Courts, 2005: Civil Bench and Jury Trials in State Courts, 2005 (Oct. 2008); Codebook, Inter-University Consortium for Political and Social Research, Civil Justice Survey of State Courts, 2005 [United States], Study No. 23862. See also Theodore Eisenberg \& Michael Heise, Judge-Jury Difference in Punitive Damages Awards: Who Listens to the Supreme Court? 8 J. Empirical Legal Stud. 325, 329-30 (2011) (describing the 1992, 1996, 2001, and 2005 data sets).

${ }^{18}$ For a general description of the appeals data set, see Codebook, Inter-University Consortium for Political and Social Research, Civil Justice Survey of Trials on Appeal, 2005 [United States], Study No. 32501. This study focuses on primary appeals and excludes from analyses the 226 secondary (or tertiary) appeals. For a similar analytical approach, see Donald J. Farole \& Thomas H. Cohen, Bureau of Justice Statistics Special Report: Appeals of Civil Trials Concluded in 2005 (Oct. 2011). Of the 1,027 cases that involved an adverse appeal, 5 (or 0.4 percent) remained pending at the end of the December 2009 study period and were thus excluded from analyses.
} 
expectations were met. Discarding the small subgroup of nonadverse appeals generates a pool of usable appeals and permits a more accurate picture of appeals by plaintiffs and defendants from trial court judgments entered against them. The appeal rate, drawn from the pool of adverse appeals, is the percentage of trial court judgments for one party or the other that the losing party puts onto the appellate docket. ${ }^{19}$ Once merged, our state data set is the single largest and most comprehensive source of state civil appeals of which we are aware. Our final merged data set includes 1,992 usable appeals drawn from a universe of 16,910 completed trials that span much of the first decade of the 21st century. Computing reversal and affirmance rates was straightforward. The reversal rate is the percentage of appeals that generate a formal legal conclusion that either reversed ${ }^{20}$ or remanded the trial court decision. The affirmance rate, by contrast, is the percentage of cases that generated an appellate court decision affirming the trial court.

\section{Results And Discussion}

While it is one thing to think about selection effect in theoretical, abstract terms, it is quite another to see selection effects unfold. Indeed, composing our final data set that features appeals drawn from a much larger universe of completed civil trials brings selection issues front and center. Figure 1 visually traces the flow of civil litigation in state courts from trial court disposition through the appeals process. Table 1, by contrast, briefly describes a few key components of the various streams and substreams of cases in our data set. Taken together, Figure 1 and Table 1 make clear that less than 12 percent of cases disposed of by trial courts formally initiated the appeals process. Fewer cases (7.1 percent) pursued an appeal to a decision. To be sure, the parties' relative stakes in the legal dispute evolve in important ways at various stages throughout the formal litigation process. Notwithstanding dynamic and evolving stress on the Priest-Klein theory's key assumptions, the possible influence of selection effects is difficult to ignore.

\section{A. Descriptive Results}

Of those few trial court decisions that pursue an appeal to completion $(N=1,195)$, as Table 1 illustrates, only 31.4 percent disrupted the trial court decision. ${ }^{21}$ Moreover, appellate courts were more likely to disrupt jury trials than bench trials. Finally, as Table

\footnotetext{
${ }^{19}$ For a similar approach to defining the appeal rate, see, e.g., Eisenberg \& Heise, Plaintiphobia Redux? supra note 8 (excluding 20.1 percent of nonadverse appeals); Eisenberg \& Heise, Plaintiphobia? supra note 8 (excluding 16.6 percent of nonadverse appeals); Clermont \& Eisenberg, Defendants' Advantage, supra note 8. ${ }^{20}$ By "reversed" (or "disrupted") we mean that an appeals court outcome fell short of a fully affirming a trial
court outcome.

${ }^{21} \mathrm{~A}$ "disruptive" appeals court decision includes appellate outcomes that fall short of fully affirming a trial court outcome.
} 
Figure 1: Flow of state trials disposed in 123 counties that were appealed to an intermediate or highest appellate state court (2001-2004, 2005-2009).

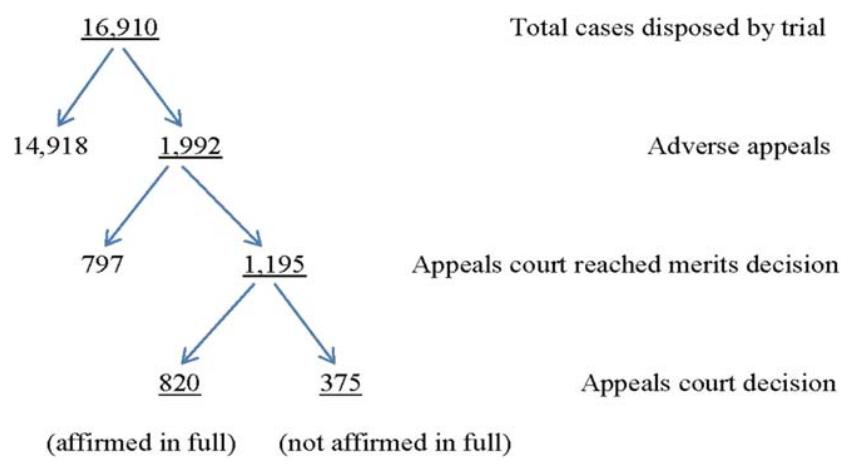

Sources: Civil Justice Survey of Trials on Appeal (2001, 2005).

2 makes clear, defendants appealing adverse trial court outcomes fared systematically better than plaintiffs on appeal. ${ }^{22}$

As Eisenberg notes, case categories matter. ${ }^{23}$ As Table 2 illustrates, appellate activity varied, sometimes substantially, across case types. Although the overall appeal rate from adjudicated trials was 11.8 percent, professional (nonmedical) malpractice (30.6 percent), employment contracts (26.3 percent), and product liability (21.7 percent) cases were appealed at rates far above the mean (11.8 percent). Case types comparatively less likely to generate appeals include motor vehicle (4.5 percent) and dangerous premises (8.8 percent). Motor vehicle cases warrant particular attention as their sheer number $(N=262)$ and low appeals rate $(4.5$ percent $)$ interact to exert important downward pressure on the overall appeal rate. ${ }^{24}$

\section{Plaintiffs' Ability to Preserve Trial Court Victories on Appeal}

Our inquiry focuses on a potential relation between a plaintiff's success rate at trial and on appeal. Insofar as Table 2 reveals important and systematic case type variations (and to facilitate comparisons to Eisenberg's prior work), we organized our data into 12 separate case types.

Figure 2 presents a scatter plot of plaintiff win rates at trial and on appeal by case types. The plaintiff's appellate win rate signals when a plaintiff successfully and fully

\footnotetext{
${ }^{22}$ For a fuller account of the asymmetric appellate outcomes, see, e.g., Eisenberg \& Heise, Plaintiphobia Redux? supra note 8 (2005-2009 data); Eisenberg \& Heise, Plaintophobia, supra note 8 (2001-2004 data).

${ }^{23}$ See generally Eisenberg, Negotiation, supra note 11 .

${ }^{24}$ The overall appeal rate increases from 11.8 percent to 15.6 percent by removing motor vehicle cases from the analysis.
} 
Table 1: State Appeals and Outcomes (2001-2004, 2005-2009)

\begin{tabular}{lcccc}
\hline & $\begin{array}{c}\text { Civil } \\
\text { Trials }\end{array}$ & $\begin{array}{c}\text { Appealed } \\
(\%)\end{array}$ & $\begin{array}{c}\text { Appealed to } \\
\text { Completion } \\
(\%)\end{array}$ & $\begin{array}{c}\text { Trial Court Decision } \\
\text { Disruption Rate } \\
(\%)\end{array}$ \\
\hline All Trials & 16,910 & 11.8 & 7.1 & 31.4 \\
$\quad \begin{array}{l}\text { Jury trials } \\
\text { Bench trials }\end{array}$ & 12,592 & 11.2 & 6.9 & 33.3 \\
Party Appealing & 4,318 & 13.4 & 7.5 & 26.1 \\
$\quad \begin{array}{l}\text { Defendant } \\
\text { Plaintiff }\end{array}$ & - & 12.0 & 6.8 & 41.2 \\
$N$ & - & 11.8 & 7.5 & 21.3 \\
\hline
\end{tabular}

Sources: Civil Justice Survey of State Courts (2001, 2005); Civil Justice Survey of Trials on Appeal (2001, 2005).

defended a trial court victory against a defendant's appeal. Figure 2 illustrates, for example, that in motor vehicle cases (labeled "auto" in Figure 2), plaintiffs won approximately 60 percent of the trials (on the horizontal or "x" axis) and preserved their trial

Table 2: State Appeal and Trial Court Decision Disruption Rates, by Case Category and Trial Type

\begin{tabular}{|c|c|c|c|c|c|c|c|c|}
\hline \multirow[b]{2}{*}{ Case Category } & \multicolumn{4}{|c|}{ Appeals } & \multicolumn{3}{|c|}{$\begin{array}{l}\text { Trial Court Decision Disruption } \\
\text { Rates (\%) }\end{array}$} & \multirow{2}{*}{$\begin{array}{c}\text { Significance } \\
\text { of }\end{array}$} \\
\hline & Filed & $\begin{array}{l}\text { Filed } \\
(\%)\end{array}$ & Completed & $\begin{array}{l}\text { Completed } \\
(\%)\end{array}$ & Overall & Defendants & Plaintiffs & \\
\hline All cases & 1,992 & 11.8 & 1,195 & 60.0 & 31.4 & 41.2 & 21.3 & 0.000 \\
\hline Motor vehicle & 262 & 4.5 & 152 & 58.0 & 22.4 & 29.9 & 16.5 & 0.053 \\
\hline Assault, slander, libel & 93 & 14.4 & 50 & 53.8 & 38.0 & 65.4 & 8.3 & 0.000 \\
\hline Product liability & 64 & 21.7 & 46 & 71.9 & 37.0 & 44.0 & 28.6 & 0.363 \\
\hline Dangerous premises & 158 & 8.8 & 88 & 55.7 & 27.3 & 31.8 & 22.7 & 0.473 \\
\hline Medical malpractice & 266 & 14.4 & 163 & 61.3 & 27.0 & 32.7 & 24.1 & 0.266 \\
\hline Prof. malpractice & 45 & 30.6 & 29 & 64.4 & 24.1 & 38.9 & 0.0 & 0.026 \\
\hline Other tort & 111 & 15.4 & 81 & 73.0 & 28.4 & 38.6 & 16.2 & 0.029 \\
\hline Employment contract & 160 & 26.3 & 96 & 60.0 & 41.7 & 51.9 & 28.6 & 0.024 \\
\hline Fraud & 181 & 19.7 & 112 & 61.9 & 42.9 & 52.1 & 26.8 & 0.011 \\
\hline Lease & 54 & 13.3 & 25 & 46.3 & 28.0 & 42.9 & 9.1 & 0.090 \\
\hline Other contract & 515 & 15.8 & 292 & 56.7 & 31.5 & 40.1 & 20.0 & 0.000 \\
\hline Property & 83 & 17.2 & 61 & 73.5 & 32.8 & 36.4 & 30.8 & 0.778 \\
\hline Tort & 999 & 8.9 & 609 & 61.0 & 27.6 & 37.3 & 19.4 & 0.000 \\
\hline Contract & 910 & 17.5 & 525 & 57.7 & 35.6 & 45.1 & 22.4 & 0.000 \\
\hline Property & 83 & 17.2 & 61 & 73.5 & 32.8 & 36.4 & 30.8 & 0.778 \\
\hline Jury trial & 1,414 & 11.2 & 873 & 61.7 & 33.3 & 44.0 & 22.0 & 0.000 \\
\hline Judge trial & 578 & 13.4 & 322 & 55.7 & 26.1 & 33.3 & 18.8 & 0.003 \\
\hline$N$ & 1,992 & & 1,195 & & 375 & 250 & 125 & \\
\hline
\end{tabular}

Notes: The "Trial Court Decision Disruption Rates (\%)" columns for defendants and plaintiffs are the rates at which an appealing defendant and plaintiff, respectively, achieved appellate reversal or remand of a trial court judgment. The final column, "Significance of D - P Difference," tests the statistical difference between the defendants' and plaintiffs' reversal rates using Fisher's exact test.

SOurCEs: Civil Justice Survey of Trials on Appeal (2001, 2005). 
Figure 2: Relation between plaintiff success rates at trial and on appeal, by case type.

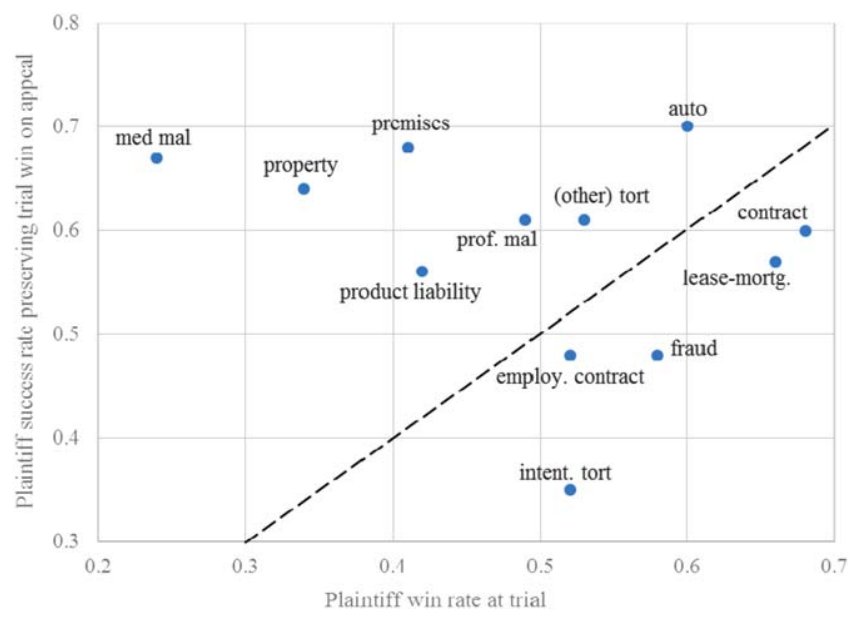

Notes: The dashed line (- - ) illustrates where the trial and appellate win rates are equal. Total number of trials $(N=16,910)$; total number of completed appeals brought by defendants $(N=607)$.

SourCEs: Civil Justice Survey of Trials on Appeal (2001, 2005).

wins in just over 70 percent of the appeals (on the vertical or "y" axis) brought by defendants. Similarly, while plaintiffs won only 24 percent of the medical malpractice cases at trial, they successfully defended their trial court victories in approximately 67 percent of the medical malpractice appeals brought by defendants. (The Appendix presents a complete list of plaintiff trial and appellate success rates.)

A naive interpretation of the Priest-Klein theory predicts the absence of an association between a plaintiff's success at trial and subsequent success preserving that success on appeal. By finding a "strong positive relation between success at pretrial motion and success at trial," however, results from Eisenberg's study of federal civil cases pose something of a challenge to the Priest-Klein theory. Results from our study depart from Eisenberg's and in so doing do not conflict with what the Priest-Klein model naïvely implies.

A visual inspection of the scatter plot in Figure 2 neither implies a linear relation nor, for that matter, any other obvious relation between a plaintiff's success at trial and on appeal. Case types found below (and toward the lower-right quadrant) the diagonal dashed line indicate case types where plaintiffs fared comparatively worse on appeal than at trial. Case types located above the diagonal dashed line (and toward the upperleft quadrant), by contrast, include those case types where plaintiffs were comparatively more successful on appeal than at trial. For example, while plaintiffs' success rate at trial for intentional torts exceeded 50 percent (0.52), those plaintiffs' success rate fell to 35 percent when it came to trying to preserve a favorable trial court outcome that was appealed. Medical malpractice cases illustrate the opposite trend. Specifically, while plaintiffs' success rate at trial was only 24 percent, those plaintiffs' success rate on warding off an adverse appellate outcome jumped to 67 percent. 
Table 3: Binomial Regression Results

\begin{tabular}{|c|c|c|c|c|}
\hline $\begin{array}{l}\text { Plaintiff Successfully } \\
\text { Preserves a Trial Cour } \\
\text { Win on Appeal, by } \\
\text { Case Type }(=1)\end{array}$ & Coeff. & Std. Er. & $\mathrm{p}$ & [95\% C.I. $]$ \\
\hline $\begin{array}{l}\text { Plaintiff win rate at } \\
\text { trial, by case type }\end{array}$ & -0.535 & 0.624 & 0.391 & {$[-1.76,0.69]$} \\
\hline Constant & 0.624 & 0.347 & 0.072 & \\
\hline $\begin{array}{l}\text { Plaintiff win rate at } \\
\text { trial, by case type }\end{array}$ & $\begin{array}{l}\text { Odds Ratio } \\
0.586\end{array}$ & $\begin{array}{c}\text { Std. Er. } \\
0.366\end{array}$ & $\begin{array}{c}\mathrm{p} \\
0.391\end{array}$ & $\begin{array}{l}{[95 \% \text { C.I. }]} \\
{[0.17,1.99]}\end{array}$ \\
\hline Constant & 1.867 & 0.648 & 0.072 & {$[0.95,3.69]$} \\
\hline
\end{tabular}

Notes: We estimated the model using the "glm" command (with a binomial family and logit link function) in Stata (v.14.1). The "binreg" command yielded identical results.

SOURCES: Civil Justice Survey of Trials on Appeal (2001, 2005).

\section{B. Regression Results}

We now turn to whether our general descriptive finding, an absence of a systematic positive relation between a plaintiff victory at trial and a successful defense of that trial court outcome on appeal, illustrated by Figure 2, survives more sophisticated regression analysis. To do so, we estimated a binomial regression equation. The binomial distribution with parameters $N$ and $p$ is the common discrete probability distribution of the number of "successes" in a sequence of $N$ independent binary outcomes (Bernoulli trials) with a success rate, $p$. In our setting, for the $i^{\text {th }}$ case type, the number of appeal trials $\left(N_{i}\right)$ and the number of wins on appeal were compiled. The model treats a plaintiff's success on appeal $\left(p_{i}\right)$ in each case type as a function of the plaintiff's case type success rate at trial. This type of regression modeling strategy falls within the domain of generalized linear models for the binomial family and in our analysis uses the logit link function.

Results from our binomial regression estimation, presented in Table 3, comport with the descriptive results presented in Figure 2. Specifically, results in Table 3 suggest no statistically significant relation between plaintiff success at trial and on appeal. Moreover, even though statistical significance is not achieved, it is notable that the coefficient of interest is negative. The negative regression coefficient $(-0.535)$ corresponds with an odds ratio of 0.586 and suggests prevailing plaintiffs confront a 41.4 percent reduction of the odds of winning on appeal.

\section{Robustness Check}

As a formal matter, we are mindful that we draw from the Priest-Klein selection theory the prediction of the absence of an association between plaintiff success at trial and subsequent success on appeal. In contrast to Eisenberg's findings, results from our descriptive and regression analyses do not permit rejecting the hypothesized prediction implied by Priest-Klein. That is, we draw evidence for our prediction from the absence of statistical significance. However, rather than assume, ex ante, the absence of an association between plaintiff success at trial and subsequent success on appeal, it might make more 
intuitive sense to expect such a relation, as Eisenberg's results suggest. In so doing, we consider whether our null findings reflect actual "zero" effects rather than a more common "failure to detect a statistical difference" effect. ${ }^{25}$

While a large literature in biostatistics-influenced heavily by pharmacological research-and a growing literature in political science directed us to various equivalence testing approaches,${ }^{26}$ limitations to our data and their structure restricted our options in developing a robustness check. Exploring relevant means, however, was possible. Plaintiffs won 53.4 percent of the trials $(N=16,762)$. For those plaintiffs who won at trial and had to defend that victory on appeal from the defendant $(N=607)$, the plaintiff win rate on appeal was 58.8 percent. Although a kernel density plot, presented in Figure 3, conveys an overall visual impression of congruence, the slightly higher mean plaintiff win rate at the appellate level (53.4 vs. 58.8 percent) is also clear.

Bowing to structural data limitations, we resorted to testing for equivalence of observed raw mean differences with a two-one-sided test (TOST) ${ }^{27}$ As Rainey notes, such a test enables scholars "to make more compelling arguments for their hypothesis of a negligible effect by explicitly testing whether meaningful effects are plausible."28 Priest-Klein theory suggests that, due to selection effects, the plaintiff trial win rate should approximate the plaintiff appeals win rate. Eisenberg's findings of a relation between plaintiff pretrial motion and trial wins conflict with what Priest-Klein theory predicts and, as a consequence, prompt us to assess whether the observed difference in the plaintiff trial and appeals win rates is nonetheless statistically similar enough for practical purposes.

To execute our equivalence testing robustness check we specified in advance that a difference in mean plaintiff win rates at trial and on appeal below 10 percent is not substantively meaningful. ${ }^{29}$ We generated two one-sided test statistics and applied the

\footnotetext{
${ }^{25}$ For a similar approach in the legal literature, see, e.g., Roger Michalski \& Abby Wood, Twombly and Iqbal at the State Level (unpublished manuscript, 2016). We thank an anonymous reviewer for prompting us to expand this point.

\begin{abstract}
${ }^{26}$ For a discussion, see, e.g., Michalski \& Wood, Twombly and Iqbal, supra note 25; Erin Hartman \& F. Dnaiel Hidalgo, What's the Alternative?: An Equivalence Approach to Balance and Placebo Tests (unpublished manuscript, Nov. 30, 2015); Carlisle Rainey, Arguing for a Negligible Effect, 58 Am. J. Pol. Sci. 1083 (2014); Stefan Wellek, Testing Statistical Hypotheses of Equivalence and Noninferiority (2010); W.J. Westlake, Symmetrical Confidence Intervals for Bioequivalence Trials, 32 Biometrics 741-44 (1976). For an overview of equivalence testing in political science, see, e.g., Rainey, id.
\end{abstract}

\footnotetext{
${ }^{27}$ In Stata v.14, the relevant command is "tostti".

${ }^{28}$ Rainey, supra note 26 , at 1083 .
}

\footnotetext{
${ }^{29}$ With regard to our decision to fix our "tolerable difference interval" (or "delta") at 10 percent, we note that among our 12 case types, seven involved differences in plaintiff trial and appeal win rates that are greater than 10 percent and five case types involved differences less than 10 percent. Also, while a standard $t$ test reveals that the difference between the mean plaintiff trial and appeals win rates achieves statistical significance $(t=-2.567$; $p<0.05)$, in the standard test the null hypothesis is that the two means are equal. In equivalence testing, by contrast, the null hypothesis is that the difference in the means is greater than our tolerable difference interval (10 percent) and the research hypothesis, in keeping with Priest-Klein theory, is that the difference in the means is not greater than 10 percent (or, stated differently, that the two means are not functionally dissimilar).
} 
Figure 3: Kernel density estimates of plaintiff win rates at trial and on appeal.

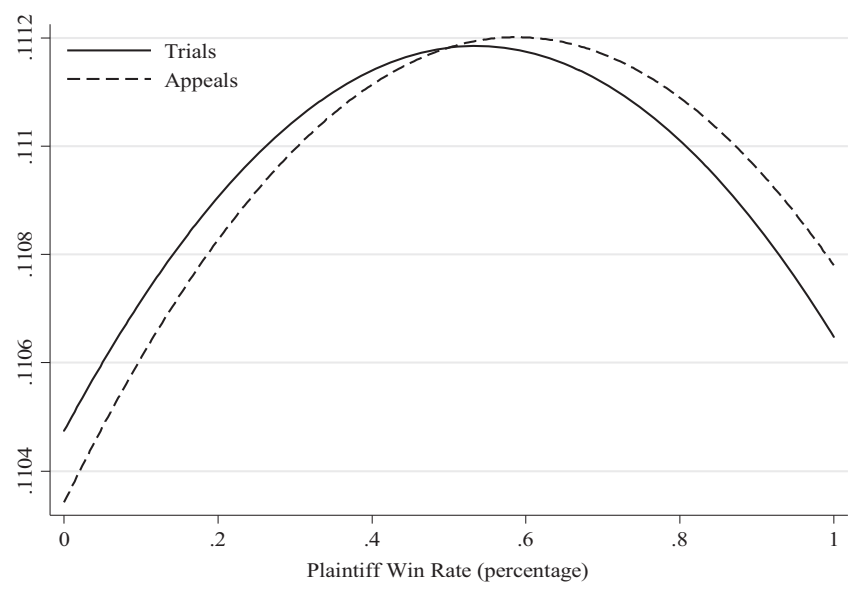

Sources: Civil Justice Survey of Trials on Appeal (2001, 2005).

Bonferroni correction for multiple testing, so that the two null hypotheses were tested at the 0.025 level. Results from equivalence testing suggest that, as Priest-Klein implies, the observed difference in plaintiff trial and appeals win rates are not functionally dissimilar. Our equivalence testing results, along with our main results, generally comport with what Priest-Klein theory suggests and this consistency contributes to our confidence in our main regression results.

While we find little systematic empirical support for the hypotheses that a plaintiff victory at trial corresponds with the plaintiff's successfully preserving that trial court victory on appeal, Eisenberg, by contrast, found a statistically significant relation between plaintiffs' pretrial motion success rates and plaintiffs' success at trial. ${ }^{30}$ What may account for these seemingly conflicting findings? Do they, in fact, even suggest a meaningful conflict? We consider practical and conceptual factors that provide necessary context for our findings and their relation to Eisenberg's earlier findings.

2. Differences in the Nature of the Relation Between Pretrial Motions and Trials and Trials and Appeals

Eisenberg's research focus and ours differ in one crucial way and the difference raises an important conceptual issue. While Eisenberg's study explores the relation between the pretrial and trial outcome stages, our study, by contrast, explores the relation between trial and appellate outcomes. Consequently, although important events

\footnotetext{
${ }^{30}$ It is important to note that Eisenberg's (1991) paper used the logit transformation of the plaintiff success rate in each case type as the dependent variable as a model was fit using a weighted least squares regression. In the early 1990s, there was a lack of convenient statistical software for fitting generalized linear models and, as a consequence, the weighted least squares estimation was routinely used. Our study, however, benefits from the more recently developed generalized linear models for the binomial family.
} 
separate pretrial motions and trial outcome stages in a trial, particularly settlement activity that takes place following (and in many instances owing to) pretrial motion resolution, Eisenberg focuses on a single unit of litigation analysis-a single civil trial. Given Eisenberg's analytic focus on a single trial, one might more likely expect, ex ante, to find a higher association between plaintiff success at the pretrial motion and trial outcomes stages, as while they are distinct activities, these activities take place within a single trial. As well, Eisenberg's data cannot differentiate among the array of possible pretrial motions (including failure to state a claim and summary judgment) whose resolution can have quite different implications for a trial both in terms of the claims that survived and information to both parties on the ultimate likelihood of success.

Our study's focus, by contrast, explores a potential relation between a trial and an appeal. Unlike the relation between a trial and its preliminary motions, the relation between a trial and a subsequent appeal is, by comparison, more distant and separate. Thus, while it remains plausible to understand a trial court decision and a subsequent contested appeal of that trial court outcome as taking place within the context of a single, unified piece of litigation, we find it more plausible to construe the context as involving two distinct, though obviously related, pieces of litigation. Moreover, the trial outcome itself provides litigants with a critical piece of new information that informs strategic litigation decisions going forward. To the extent that settlement activity takes place after a concluded trial and before a concluded appeal, such activity, according to Priest and Klein, should further remove potential appeals at both margins and leave those appeals where the outcome is objectively unclear. ${ }^{31}$ If so, such settlement activity would further reduce the predictive force of a trial outcome on an appellate outcome.

Evidence emphasizing differences between the trial and appellate contexts abounds. In the trial setting, pretrial and trial activity spring from a shared piece of litigation. The skill sets necessary to successfully navigate through pretrial motions and a trial are quite similar and, as a result, the same attorney (or group of attorneys) handles pretrial and trial tasks in most civil litigation.

Trial and appellate work, however, typically involve distinctive skill sets. Indeed, the legal market reflects this distinctiveness as some niche law firms specialize in either trial or appellate work. As well, most large, sophisticated law firms have separate trial and appellate departments or working groups. Finally, even the insular (and admittedly arcane) world of law reviews reflects the differences between trial and appellate practices as they warrant separate specialty journals. The American Bar Association's section on litigation publishes the Trial Practice Journal and the University of Arkansas-Little Rock School of Law hosts the Journal of Appellate Practice and Process.

Differences between trials and appeals come into sharper focus in the criminal context. ${ }^{32}$ Scholars note that systematic differences in the institutional characteristics

\footnotetext{
${ }^{31}$ See generally Priest \& Klein, supra note 1.

${ }^{32}$ See, e.g., A.C Pritchard, Auctioning Justice: Legal and Marketplace Mechanisms for Allocating Criminal Appellate Counsel, 34 Am. Crim. L. Rev. 1161, 1178 (1997) (observing critical differences in the criminal trial and appellate contexts).
} 
between trial and appellate courts influence judicial preferences. ${ }^{33}$ Indeed, one increasingly sees arguments that, where possible and economically feasible, trial counsel should incorporate an appellate specialist during criminal trials to better prepare for a possible appeal. Separate specialists are deemed necessary due to the "substantial differences one encounters on appeal as compared to trial." 34

To the extent that trials and appeals are better understood as distinct litigation contexts, one might be less inclined to expect to find, ex ante, a robust association between a plaintiff's success at trial and success on appeal. Or, more specifically, one would be less inclined to find an association in our trial and appellate setting than in Eisenberg's pretrial and trial setting. ${ }^{35}$ After all, studies of the possible relation between plaintiff success at trial and on appeal, such as ours, move the focus from Eisenberg's single unit of litigation analysis-a trial— to two discrete units of litigation analysis-a trial and an appeal. Unlike the litigation flow from a pretrial motion to a trial conclusion, the litigation flow from a concluded trial to a concluded appeal requires distinct activity on behalf of the plaintiff. This activity triggers an entire new and separate set of litigation fees and costs as it requires a plaintiff to affirmatively launch an entirely separate legal action.

\section{Endowment Effect}

The endowment effect may also contribute to differences between Eisenberg's study and our own, particularly as it relates to settlement activity. Eisenberg's studies compare plaintiff success rates at the pretrial and trial stages and our study examines plaintiff success at the trial and appellate stages. Although both sets of studies exclude settled cases, the probability of settlement may systematically differ owing, partly, to variation in the endowment effect's influence.

The endowment effect is typically explained as a function of "loss aversion." 36 Loss aversion suggests that individuals value losses more than equivalent gains. ${ }^{37}$ This behavioral economic insight is taken as a given in the academic literature as legal scholars claim "in more than a thousand of articles, that the endowment effect leads to suboptimal

\footnotetext{
${ }^{33}$ See, e.g., Christopher R. Drahozal, Judicial Incentives and the Appeals Process, 51 SMU L. Rev. 469, 471 (1998); Karl N. Llewellyn, Law and the Social Sciences-Especially Sociology, 62 Harv. L. Rev. 1286, 1289 (1949) (describing the difference between a trial and an appeal as "huge").

${ }^{34}$ See, e.g., Hon. Joseph W. Hatchett \& Robert J. Telfer, III, The Importance of Appellate Oral Argument, 33 Stetson L. Rev. 139, 147 (2003).

${ }^{35}$ Indeed, some may argue a stronger form of this point. Specifically, that due to the important differences between the trial and appeals contexts, one might plausibly assume, ex ante, that our results would not necessarily comport with Eisenberg's. We thank Professor Kevin Clermont for bringing this point to our attention.

${ }^{36}$ See, e.g., Russell Korobkin, The Endowment Effect and Legal Analysis, 97 Nw. U. L. Rev. 1227, 1250 (2003).

${ }^{37}$ See generally Daniel Kahneman \& Amos Tversky, Prospect Theory: An Analysis of Decision Under Risk, 47 Econometrica 263 (1979).
} 
allocation of important entitlements." ${ }^{38}$ Recent scholarship focuses not on whether the endowment effect exists, but on how it may vary across an array of legal domains.

The endowment effect's potentially differential influence on Eisenberg and our studies warrants discussion. In Eisenberg's studies, the plaintiffs' decisions about whether to resist any settlement offers after pretrial motions and before trial took place without any "cash in hand" from the defendant. In contrast, in our study, plaintiff decisions about whether to persist through an appeal after a successful trial outcome took place having already secured a legal award, denominated in dollars. It is the existence of a legal award that separates our study from Eisenberg's in ways that open the door for systematically different endowment effect influences. Specifically, if the endowment effect literature is correct, we should expect plaintiffs in our study to withstand otherwise economically rational settlement offers to a degree greater than the plaintiffs in Eisenberg's studies. If so, this differential filtering would generate systematically different selection effects that would, in turn, contribute to systematically different pools of plaintiffs. Systematically different sets of plaintiff pools would certainly help further account for why our results differ from Eisenberg's.

\section{Federal Versus State Litigation Data}

Another important structural difference that distinguishes our study and Eisenberg's involves data. While the Eisenberg papers exploit federal civil litigation data, our study uses state court civil litigation data. To be sure, it is admittedly not obvious why the state and federal civil litigation contexts might differ in terms of the relation between a plaintiff trial victory and the prospects of preserving that plaintiff victory on appeal. That state and federal litigation streams systematically differ in important ways, however, is widely acknowledged in the literature.

Commentators note important differences that separate federal and state court litigation. One notable distinction involves litigation cost. The comparatively higher costs associated with federal litigation may reflect systematic differences in the types of cases routed to federal and state courts. For example, in fiscal year 1982 the federal government spent approximately $\$ 1,740$ to process the typical torts claim litigated in federal courts. Federal spending on tort claims' processing exceeded spending by state courts to process tort litigation by more than 300 percent. ${ }^{39}$ What accounts for such a cost difference between federal and state courts? Some of these cost differences can be explained by the "complex" nature of some federal cases and because federal courts seldom hear the relatively inexpensive domestic relations, probate, and mental health cases processed by comparatively low-cost state courts. ${ }^{40}$ Even if federal and state courts

\footnotetext{
${ }^{38}$ Jennifer Arlen \& Stephan Tontrup, Does the Endowment Effect Justify Legal Intervention? The Debiasing Effect of Institutions, 44 J. Legal Stud. 143, 144 (2015).

${ }^{39}$ Edward Brunet, Measuring the Costs of Civil Justice, 83 Mich. L. Rev. 936-37 (1985) (reviewing J.S. Kakalik \& R. L. Ross, Costs of the Civil Justice System: Court Expenditures for Various Types of Civil Cases (RAND 1983)).
}

${ }^{40}$ Id. 
processed similar case types, differences in federal and state procedural rules may contribute further to case disposition cost differences. ${ }^{41}$

The streams of federal and state appeals likely systematically differ, and these differences contribute to different federal and state appeal rates. For example, unlike in the state court context, in the federal context litigants must either raise a federal question $^{42}$ or plead for damages that exceed $\$ 75,000$ and establish diversity between parties. $^{43}$ These different jurisdictional requirements might route systematically higherstakes cases into federal courts and away from state courts. Moreover, just as higherstakes cases tended to be litigated to trial more than their lower-stakes counterparts, higher-stakes cases might similarly skew an unsuccessful party's decision to appeal. ${ }^{44}$ Therefore, if federal trials typically involve higher-stake claims than those pursued in state trials, we should expect this difference to also contribute to differences in the federal and state settings in terms of decisions to appeal. ${ }^{45}$

In addition, the case type differences that distinguish federal and state civil litigation also warrant note. In particular, while motor vehicle cases dominate state trials, such cases account for a much smaller fraction of federal trials. ${ }^{46}$ It also turns out that case type influences the proclivity to appeal. While motor vehicle cases dominate state civil litigation, motor vehicle cases are among the least likely case type to generate an appeal. ${ }^{47}$ As Table 2 illustrates, motor vehicle cases' appeal rate (5.0 percent) is the lowest across all individual case types. Consequently, the sheer number of motor vehicle cases and their low appeal rate interact in a manner that further distinguishes federal and state civil trial and appellate litigation.

Finally, state and federal appellate courts evidence interesting differences when it comes to reversal rates. In the state context, and drawing from 2001-2004 and 20052009 data cohorts, overall reversal rates ranged from 30.8 to 32.1 percent. ${ }^{48}$ By contrast, for federal courts during 1988-1997, the overall reversal rate was 18.4 percent. ${ }^{49}$

\footnotetext{
${ }^{41} \mathrm{Id}$.

${ }^{42} 28$ U.S.C. $\$ 1331(2006)$.

${ }^{43} 28$ U.S.C. $§ 1332(a)(2006)$.

${ }^{44}$ Richard A. Posner, Economic Analysis of Law (1992); Samuel R. Gross \& Kent D. Syverud, Getting to No: A Study of Settlement Negotiations and the Selection of Cases for Trial, 90 Mich. L. Rev. 319 (1991).

${ }^{45}$ Although the intuition that structural differences between federal and state courts might route systematically higher-stakes cases into federal courts strikes us as plausible, it bears noting that the intuition lacks empirical verification. Our data do not permit reliable assessments about the actual case in controversy.

${ }^{46}$ Theodore Eisenberg, John Goerdt, Brian Ostrom \& David Rottman, Litigation Outcomes in State and Federal Courts: A Statistical Portrait, 19 Seattle U.L. Rev. 433 (1996).

${ }^{47}$ See Eisenberg \& Heise, Plaintiphobia Redux? supra note 8, at 114, tbl.2.

${ }^{48}$ See id. at 110 , tbl.1.

${ }^{49} \mathrm{Id}$.
} 
Obviously, there is no single way to interpret these differential reversal rates. The comparatively low federal reversal rate (18.4 percent) may reflect that either federal trial courts got things correct or, conversely, that federal appeals courts are peculiarly loathe to unsettle trial court decisions. On the other hand, the comparatively high reversal rates in state courts (30.8 and 32.1 percent) may imply the opposite.

5. Structural Differences Separating the Federal and State Court Systems: The Role of Magistrate Judges

Important structural differences between federal and state court systems may also help explain why Eisenberg's results find important relations between plaintiff success at the pretrial and trial stages but our results do not find such a relation in the trial and appeal stages. Because of the various (and varying) tasks that magistrate judges perform in federal district courts, including in federal courts between 1978-1985, it remains a possibility that the same person (a magistrate judge) may have presided over a case's pretrial motions and the trial itself. That is, the relations Eisenberg sought to explore may involve a single judge rather than different judges reaching their own independent conclusions. If a case's pretrial motions and trial were decided by the same individual, one might expect, ex ante, for plaintiff success at the pretrial and trial stages to correlate. To assume otherwise would assume that a magistrate judge would rule in favor of the plaintiff in one context but not in the other. While certainly a technical possibility, common sense suggests this is less than likely.

Our state-level civil trial data, by contrast, permit an analysis of possible relations between a plaintiff's success at trial with the plaintiff's ability to successfully preserve the trial success on appeal. In our state context, trial and appellate court decisions involved two separate judges. The additional independence generated by two separate judges presiding over trials and appeals increases the degree of independence of each judicial outcome. As the degree of independence increases, our ex ante expectation of an association between plaintiff success at trial and on appeal decreases. From this perspective, not only do Eisenberg's findings comport with expectations (to the extent that pretrial motions and trials were presided over by the same person), but it would also help explain why our findings depart from Eisenberg's. That is, we could better harmonize our findings with Eisenberg's if we assumed (however unreasonably) that all of the case-level judicial outcomes included in Eisenberg's federal data set were decided by the same individual. On the other hand, if we take the other extreme assumption—and assume that different judicial officers participated in the judicial outcomes included in Eisenberg's federal data set-then Eisenberg's federal data set and our state data set structurally resemble one another and, if so, the inconsistent findings are more difficult to reconcile. Because it is impossible to discern magistrate judges' roles in Eisenberg's data sets, however, it is similarly impossible to assess the potential influence attributable to a lack of independence in the pretrial and trial decisions.

\section{Temporal Issues}

The passage of time is another practical factor that distinguishes the data in our study from the data in Eisenberg's prior work. The federal civil cases that Eisenberg studied were drawn from the 1978-1985 timeframe, while the state civil cases in our study were 
drawn from the 2001-2009 timeframe. In addition to possible systematic differences between federal and state civil litigation (discussed above), the passage of between 16 and 32 years may also distinguish the two studies.

While data limitations preclude a granular examination of time trends and their influence on the streams of federal and state civil cases, one obviously important trend during this time period is a steady diminution of cases tried to conclusion over time. Two factors warrant particular attention. First, as Professor Marc Galanter noted in his seminal study, the percentage of complaints filed in federal courts that resulted in some form of disposition other than a completed trial increased by a factor of five between 1962 and 2002, and the percentage of cases that culminated in a completed trial dropped by 20 percent. ${ }^{50}$ Galanter found a similar "vanishing trial" trend in state courts: between 1976 and 2002, civil trials as a percentage of total dispositions fell from 36.1 to 15.8 percent. ${ }^{51}$ Thus, during the years that separate Eisenberg's and our data sets, the absolute and relative number of completed trials dropped considerably.

A second factor distinguishing the federal and state civil data sets involves a similarly vanishing civil appeal. Between 1988 and 1997, Professors Clermont and Eisenberg found that 28.7 percent of all completed federal civil trials initiated the appeals process. $^{52}$ Of those, 12.2 percent pursued the appeal to completion. ${ }^{53}$ The state civil court context, however, evidenced a less robust appetite for both initiating and completing appeals. Between 2001 and 2004, 12 percent of all completed state civil trials initiated the appeals process and, of those, 6.8 percent pursued the appeal to completion. ${ }^{54}$ Between 2005 and 2009, while the appeals rate declined slightly to 11.6 percent, the percent of appeals taken to completion increased slightly by 0.5 percent. ${ }^{55}$

While the "vanishing trial" and "vanishing appeal" are interesting and important in their own right, salient to this study is the likely possibility that the stream of federal cases in Eisenberg's 1978-1985 data set may systematically differ from the stream of state cases in our 2001-2009 data set. To the extent that systematic differences exist, these differences may help account for our conflicting results.

\footnotetext{
${ }^{50}$ Marc Galanter, The Vanishing Trial: An Examination of Trials and Related Matters in Federal and State Courts, 1 J. Empirical Legal Stud. 459, 461-63 (2004), tbl.1.

${ }^{51}$ Id. at 506-08, tbl.4, fig. 32.

${ }^{52}$ Kevin M. Clermont \& Theodore Eisenberg, Plaintiphobia in Appellate Courts: Civil Rights Really Do Differ from Negotiable Instruments, 2002 U. Ill. L. Rev. 947, 952 (2002), tbl.1.

${ }^{53} \mathrm{Id}$.

${ }^{54}$ See Eisenberg \& Heise, Plaintiphobia Redux? supra note 8, at 110, 111-12, tbl.1.

${ }^{55} \mathrm{Id}$.
} 


\section{Conclusion}

While important factors-differences in the relation between pretrial motions and trials and trials and appeals, the source of data (federal vs. state), and time-separate our findings from Eisenberg's findings, results from our analyses underscore once again the salience of selection effects on litigation. More specifically, because we find no systematic, positive relation between a plaintiff's victory at trial and the plaintiff's likelihood of preserving that success on appeal, our results imply that a plaintiff's decision to pursue litigation to a trial court conclusion is analytically distinct from the plaintiff's decision to defend an appeal of its trial court win brought by a disgruntled defendant. Our findings imply that state civil trials and subsequent appeals are better understood as distinct processes.

Contributing to the distinctiveness of civil trials and appeals is the additional layer of selection that arises post trial court outcome and throughout the appeals process (up to, but not including, an appellate court judgment). After all, as Table 1 illustrates, defendants who lost in state civil trials initiated the appeals process in only 12 percent of all concluded state civil trials. Fewer still, 6.8 percent, culminate in an appeals court decision. Our findings suggest that these 12 percent and, even more importantly, the 6.8 percent of appeals pursued to formal completion likely systematically differ from the universe of completed trial court decisions favoring plaintiffs from which the appeals emerge.

\section{Appendix}

Table A1

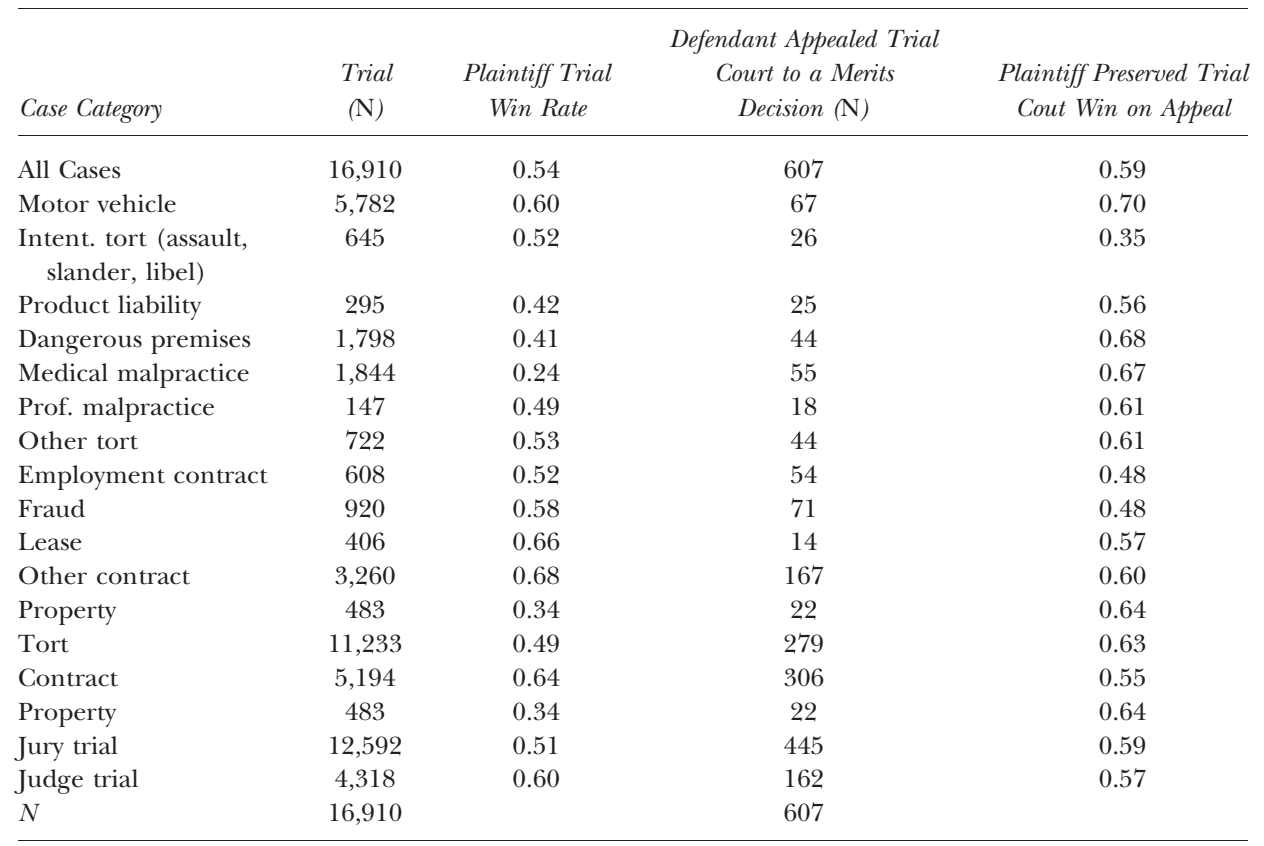

Sources: Civil Justice Survey of Trials on Appeal (2001, 2005). 